\title{
THE LENDING POLICIES OF BANKS IN NON-METROPOLITAN AREAS AND THE IMPLICATIONS FOR LOCAL ECONOMIC DEVELOPMENT: COMMENT
}

\section{G. Richard Dreese*}

This paper contains a confusing series of assumptions, (lack of capital in rural areas) arguments, (financial factors are a necessary but not sufficient condition for growth) and hypotheses (bank size and loan/asset ratios a re positively related). The meager evidence that is preeented supports the hypothesis that large banks and small banks have different asset portolios and therefore size and behavior are related. From this limited information the authors push for more liberal branching to encourage la rger banks which will stimulate regional economic growth.

The data do not strongly or consistently support any of the hypotheses of the study since the differences between banks is slight beyond the $\$ 10 \mathrm{mil}$ lion member banks and $\$ 25$ million non-member banks. The results do not justify any strong policy statements.

Beyond the limited value of the present results the authors claim several unique features which are not in fact unique. Banksize and performance have been shown to be related in almost every variety of performance measures (see Bell and Murphy, Hester, Benston, etc.) due largely to scale economies of banks. However, it is the point at which these economies occur or disappear that needs to be discovered.

The authors claim a unique measure of portfolio analysis the, "loan to discretionary assets" ratio. The loan to asset ratio is quite common in the literature (e.g. Philadelphia Fed. REVIEW, August, 1966). In the same source this quote appears: "Large banks typically have higher loan/asset ratios and are active in the federal funds market." It is seriously questionable, moreover, to exclude cash assets as being outside a bank's discretionary control. The "money" position of a bank is possibly managed more carefully than any other bank asset. For example, cash, due from balances and excess reserves are sometimes called "managed cashassets", (e. g. Phil. Fed. REVIEW, September, 1964). The differences between member and non-member banks is a favorite topic in much literature (e.g. L. S. Mayne's THE COST OF FEDERAL RESERVE SYSTEM MEMBERSHIP, Amer., Banker's Association, 1967).

Two other comments are in order. Small banks typically a re more liquid than large banks for a combination of reasons (uncertainty about flows, maximization of security as opposed to current income, etc.). Also, using almost any measure, the authors would find size as a significant influence on bank behavior and their use of the loan/deposit ratio might even be more interesting than what they used. It is the uncertainty about deposit flows that is one of the major influences in banks decisions and it makes sense to relate loans to deposits because it emphasizes that important nexus.

Finally, there is no evidence in the paper that big banks and regional economic growth a re closely related. In my opinion the evidence in the lite rature on this subject is quite skimpy. The policy statements in the paper are thus not warranted on the basis of this paper.

*Associate Professor of Economics, West Virginia University. 
Many of the issues the authors touch on are important and need to be examined carefully. I hope the authors will examine them in a more careful and systematic way. 